\title{
DOES FARMER GROUP MEMBERSHIP ENHANCE TECHNOLOGY ADOPTION? EMPIRICAL EVIDENCE FROM TOLON DISTRICT OF GHANA
}

\author{
Hajaratu AHMED, Benjamin Tetteh ANANG * (i)
}

\author{
Address: \\ University for Development Studies, Faculty of Agriculture, Department of Agricultural Economics and Extension, \\ Nyankpala Campus, P. O. Box TL 1882, Tamale, Ghana. \\ * Corresponding author: benjamin.anang@uds.edu.gh
}

\begin{abstract}
The low adoption of improved technologies by farmers has been identified as one of the major factors affecting agricultural production and food security in many developing countries including Ghana. Farmer-based organizations have been identified as important channels for information and technology dissemination to farmers. The effect of these groups on farmers' adoption decisions has important implications for agricultural production and food security in many developing countries. This study therefore sought to examine the effect of farmer group membership on improved variety adoption by smallholder maize farmers in the Tolon District of Ghana using cross-sectional data from a sample of 160 farmers. A recursive bivariate probit (RBP) model was used to estimate the effect of group membership on adoption. The results indicate that membership in farmer groups is associated with lower adoption of improved maize varieties, which is contrary to generally held view that farmer groups promote adoption by farmers. Adoption is higher for the married and farmers with access to agricultural extension but decreases with size of herd size and cultivated land. The results underscore challenges confronting farmer-based organizations such as increasing politicization, decreasing effectiveness, and lack of support from both public and private institutions. Incentivizing farmer groups, including the apex body responsible for supervision of these groups will enhance effectiveness of farmer groups.
\end{abstract}

Keywords: Adoption, farmer-based organization, productivity, recursive bivariate probit model, Tolon district JEL: C21, D24, Q12

\section{INTRODUCTION}

Agriculture plays a major role in the development of Ghana's economy. According to ISSER (2016), the agricultural sector contributes about $20.3 \%$ to the country's gross domestic product (GDP) while more than $60 \%$ of the population depend on the sector for their livelihood (Government of Ghana, 2017). Despite the important role agriculture plays in the national economy, there has been a consistent decline in the sector's contribution to gross domestic product (GDP) in recent years. As a result, there have been several efforts towards revamping the agricultural sector to promote growth and development, especially productivity growth and overall agricultural development. These efforts include promotion and establishment of farmer-based organizations (FBOs) especially among rural farmers and measures to enhance adoption of improved agricultural technologies such as improved seeds, inorganic fertilizers, agricultural mechanization and irrigation technology.

As emphasized by Gatzweiler and von Braun (2016), one way to improve the welfare of rural people is to ensure agricultural productivity growth through technological innovations. Agricultural technology may be defined as enhancing farming activities by the use of new methods and innovations. Technology encapsulates the scientific application of knowledge to real situations while adoption is the integration of new concepts into farmers' common farming practices over a period of time (Feder et al. (1985). Adoption of improved agricultural technology is a tool for increasing agricultural production as well as increasing farm income, reducing poverty, improving standard of living and increasing food security (Mwangi and Kariuki, 2015).

Hazell et al. (2010) argued that institutional innovations play relevant role in achieving agricultural growth and development as they can assist farmers to overcome market failures. The term farmer groups, farmers' associations, farmers' cooperatives and farmer's societies can be used interchangeably (Asante et al., 2011; DENIVA, 2005; Uliwa and Fisher, 2004) and refers to a group of farmers with common interest who share experience to enhance their common objective. From a lay man's perspective, a farmer-based organization may be defined as an organization owned and controlled by the members with the aim of rendering services for mutual benefit of all its members. Several organizations, both governmental and non-governmental, support the development of FBOs in Africa on the premises that FBOs enhance access to credit, extension services, marketing of produce and farm inputs, as the nature of agriculture in Africa is on small scale (Barham and Chitemi 2009; Bernard et al. 2008; Bernard and Spielman 2009). Establishment of FBOs is encouraged by several governments to enhance poverty reduction and economic growth, improve rural access to extension delivery and credit as well as the welfare of the people (Stockbridge $\boldsymbol{e} t$ 


\section{al., 2003; World Bank 2007).}

Farmer groups are anticipated to enhance the adoption of improved agricultural technologies by members which is expected to increase agricultural productivity, commercialization and market access (MAAIF, 2010). The influence of FBOs on crop productivity has been evaluated by several researchers worldwide. These studies give mixed results suggesting both positive and negative effects of farmer groups on productivity (see Benin et al., 2011; Davis et al., 2012; Mwaura, 2014). A study by Debela et al. (2018) indicated that farmers' cooperatives enhanced income and productivity of smallholder farmers in Eastern Oromia in Ethiopia. When farmer-based organizations are adequately resourced and incentivized to serve their members, they provide benefits to the members. These benefits include access to services and input delivery which lead to improvement in farm performance and profitability. However, farmer groups may deviate from their core mandate while free-riding behaviour of some members may also reduce the groups' effectiveness. In addition, increasing politicization of FBOs has the tendency to reduce effectiveness of these groups due to political influences, favouritism, and cronyism. Thus, the contribution of farmer groups is very much related to both its internal structures and the support from governmental and non-governmental organizations. Where such support is forthcoming, farmer groups are more likely to be effective in their operations thereby enhancing adoption of technology and farm productivity of the members.

Farmer groups are voluntary organizations; hence participation is voluntary. Nevertheless, in spite of the perceived benefits of FBOs to smallholder farmers, not every farmer is willing to join these groups. The decision to join a farmer group depends on the expected utility to be gained from participation. Hence, farmers are likely to join when the benefits of joining the group is perceived to be higher than not joining. Conversely, where farmers perceived the benefits to be gained to be lower than not joining, they are not likely to join.

Farmer-based organizations are gaining popularity in recent times and becoming common in many rural areas of developing countries. However, the impact of these groups on farm outcomes especially technology adoption and productivity, remains unclear especially in the context of smallholder farming in Ghana. The objective of this paper is therefore to assess the factors influencing the decision of smallholder maize farmers to participate in FBOs in the Tolon district of northern region of Ghana and the effect that these groups have on adoption decisions of farmers and farm productivity. The study employs a recursive bivariate probit model that accounts for both observed and unobserved heterogeneity in the binary decisions, thus accounting for selection bias. Furthermore, the model can be used to assess the impact of FBO membership on adoption. The motivation behind this study is born out of the need to ascertain the effectiveness of FBOs operating in rural areas in the country and their impact on smallholder farmers vis-à-vis adoption of improved varieties and productivity. The results of the study will highlight the strengths or weaknesses of these groups and provide insight into measures to enhance group effectiveness that will promote technology adoption and farm productivity.

\section{DATA AND METHODS}

\section{Recursive bivariate probit (RBP) model}

In modelling two jointly determined binary choices or decisions, researchers typically adopt a bivariate probit approach, where the two binary choices are determined by the same set of explanatory variables. In the situation where the two binary choices are influenced by slightly different explanatory variables, a seemingly unrelated bivariate probit (SUBP) model is assumed. However, there are situations where one of the binary choice variables is a factor influencing the other choice variable. In this case, a recursive bivariate probit (RBP) model is more appropriate for the estimation. The recursive bivariate probit model consists of two probit equations with error terms that are correlated and one of the binary dependent variables is allowed to be an endogenous explanatory variable in the other equation. In this way, the RBP model can be used to evaluate the impact of a binary choice variable on another binary decision. The dependent variables under investigation in this study are dichotomous namely farmer group membership and adoption of improved varieties. Empirical investigations of binary choice decisions typically make use of latent variables to analyse the relationship between the dichotomous variable and the set of explanatory variables. In this study, a latent variable is assumed for the analysis.

It is assumed that participation in farmer-based organizations is a latent variable represented by $Y_{1}^{*}$, and that $Y_{2}^{*}$ is a latent variable measuring adoption of improved variables. Since these two latent variables are unobservable, the following specification can be used to depict the relationship between the latent variable $Y_{1}^{*}$ and the observed choice $Y_{l}$ (Eq. 1-2)

$Y_{1}^{*}=x_{1} \beta_{1}+e_{1}$
$Y_{1}=\left\{\begin{array}{l}1, \text { if } Y_{1}^{*}>0 \\ 0, \text { otherwise }\end{array}\right.$

Where: $x_{l}$ stands for the observed explanatory variables that explain participation in farmer-based organizations, $\beta_{l}$ is a vector of parameters to be estimated, and $e_{l}$ denotes a random error term.

Similarly, the decision to adopt improved varieties is modelled as a latent variable, with the following specification that represents the relationship between the latent variable $Y_{2}^{*}$ and the observed choice $Y_{2}$ (Eq. 3-4)

$$
\begin{aligned}
& Y_{2}^{*}=\partial Y_{i}+x_{2} \beta_{2}+e_{2} \\
& Y_{2}= \begin{cases}1, & \text { if } Y_{2}^{*}>0 \\
0, & \text { otherwise }\end{cases}
\end{aligned}
$$

Where: $x_{2}$ represents the observed explanatory variables explaining adoption decision, $\beta_{2}$ is a vector of parameters to be estimated, and $e_{2}$ denotes a random error term. The error terms in the two models, that is $e_{1}$ and $e_{2}$, are dependent and have a normal distribution so that (Eq. 5), 
$E\left[e_{i}\right]=E\left[e_{2}\right]=0 \quad \operatorname{var}\left[e_{1}\right]=\operatorname{var}\left[e_{2}\right]=1$
$\operatorname{cov}\left[e_{1}, e_{2}\right]=\rho$

and

Finally, a Wald test for the null hypothesis $\rho=0$ is used to test whether the two models have to be jointly estimated.

The empirical model for improved variety adoption is presented as follows (Eq.6).

$Y_{1}=\beta_{0}+\beta_{1}$ age $+\beta_{2}$ sex $+\beta_{3} e d u+\beta_{4}$ mar +

$\beta_{5} \exp +\beta_{6}$ fsize $+\beta_{7}$ hsize $+\beta_{8}$ ext $+\beta_{9}$ catt $+e_{1}$

Similarly, the empirical model for farmer group participation is presented as follows in Eq. 7.

$Y_{2}=\beta_{0}+\beta_{1}$ age $+\beta_{2}$ sex $+\beta_{3}$ edu $+\beta_{4}$ mar +

$\beta_{5}$ exp $+\beta_{6}$ fsize $+\beta_{7}$ hsize $+\beta_{8}$ ext $+\beta_{9}$ catt +

$\beta_{10}$ cred $+\beta_{11}$ subsidy $+\beta_{12}$ cost $+\beta_{13} Y_{1}+e_{2}$

Simultaneous estimation of Equations (1) and (3) using maximum likelihood gives unbiased estimates of $\beta$ and $\rho$.

\section{RESULTS AND DISCUSSION}

\section{Description of the sample}

Table 1 provides a description of the variables used in the study. Majority of the respondents $(86 \%)$ are male while $92 \%$ are married. The respondents have a mean age of 43 years and an average of 10 household members, while farm size averaged 1 hectare. Majority of the respondents (74\%) have no formal education nor access to credit (89\%). Close to $54 \%$ have access to extension service while $14 \%$ own cattle. Cattle ownership was included as a wealth indicator. In addition, majority of the respondents $(89 \%)$ have access to fertilizer subsidy. Technology adoption involves a cost to farmers and the decision to adopt depends on farmers' ability to pay and whether the cost of adoption is perceived to be high or low. The cost of adoption includes the cost of improved seeds and chemical fertilizers as well as farmers' perceptions of the riskiness of the technology. Majority of the respondents in this study perceive the cost of adoption to be high. The years of farming experience of the respondents averaged 17 years. Also, about $48 \%$ of the farmers participate in a farmers group while 50\% adopt improved maize varieties.

The descriptive statistics of the bivariate probit model variables are presented in Table 2. Farm size, sex, age, household size, and marital status of the respondents did not differ much between FBO members and adopters of improved maize varieties. On average, $25 \%$ of FBO members had formal education while $28 \%$ of adopters of improved varieties had formal education. Furthermore, $97 \%$ of FBO members were married compared to $93 \%$ of adopters. Also, $17 \%$ of FBO members had access to credit compared to $14 \%$ of adopters of improved varieties. Farmers' low access to credit is a major concern to agricultural production in the study area. The data also shows that $87 \%$ of FBO members had access to agricultural extension compared to $66 \%$ of adopters. This indicates that FBO members participated more in extension in line with the extant literature that FBOs are conduits for extension service delivery in most rural communities. The low participation of adopters in agricultural extension is contrary to a priori expectation but may be indicative of the generally low access to agricultural extension in many rural areas. Majority of the respondents did not own cattle while similar proportion of FBO members and adopters had access to fertilizer subsidy. On the other hand, $88 \%$ of FBO members perceived the cost of adoption to be high compared to $80 \%$ of adopters. Finally, farming experience did not differ between the two groups.

\section{Results of the recursive bivariate probit ( $\mathrm{RBP}$ ) model}

The results of the recursive bivariate probit model of FBO membership and improved maize variety adoption are presented in Table 3 . The likelihood ratio test of the joint equations was significant at $5 \%$ level indicating that the two equations are related. In other words, joint estimation of the two equations is appropriate, whereas individual estimation of the two models would have yielded inconsistent estimates.

Table 1 Definition and summary statistics of the variables used in the study

\begin{tabular}{|c|c|c|c|c|}
\hline Variable & Definition & Mean & Min. & Max. \\
\hline Adoption $\left(Y_{l}\right)$ & Crop variety $(1=$ improved $)$ & 0.500 & 0 & 1 \\
\hline Farmer group membership $\left(Y_{2}\right)$ & Group membership $(1=$ member $)$ & 0.475 & 0 & 1 \\
\hline Sex of farmer (sex) & Sex of farmer $(1=$ male $)$ & 0.863 & 0 & 1 \\
\hline Age of farmer (age) & Age of farmer in years & 42.93 & 18 & 90 \\
\hline Educational status $(e d u)$ & Educational status ( $1=$ educated $)$ & 0.256 & 0 & 1 \\
\hline Marital status (mar) & Marital status $(1=$ married $)$ & 0.919 & 0 & 1 \\
\hline Household size (hsize) & Number of household members & 10.24 & 1 & 25 \\
\hline Farm size $(f$ size $)$ & Farm size in hectares & 0.969 & 0.4 & 5.3 \\
\hline Access to credit (cred) & Access to credit $(1=$ access $)$ & 0.113 & 0 & 1 \\
\hline Extension access $(e x t)$ & Access to extension $(1=$ access $)$ & 0.538 & 0 & 1 \\
\hline Cattle ownership (catt) & Farmer owns cattle $(1=$ yes $)$ & 0.144 & 0 & 1 \\
\hline Subsidy (subsidy) & Access to fertilizer subsidy $(1=$ yes $)$ & 0.894 & 0 & 1 \\
\hline Cot of adoption (cost) & Cost of adoption $(1=$ high $)$ & 0.863 & 0 & 1 \\
\hline Experience $(\exp )$ & Farming experience in years & 16.88 & 2 & 50 \\
\hline
\end{tabular}


Table 2 Descriptive statistics of the recursive bivariate probit analysis variables

\begin{tabular}{lllll}
\hline Variable & FBO membership & & \multicolumn{2}{c}{ Improved variety adoption } \\
& Members & Non-members & Adopters & Non-adopters \\
\hline Sex of farmer (\%) & 0.855 & 0.869 & 0.825 & 0.900 \\
Age of farmer (years) & 44.61 & 41.42 & 42.85 & 43.01 \\
Educational status (\%) & 0.250 & 0.262 & 0.288 & 0.225 \\
Marital status (\%) & 0.974 & 0.869 & 0.925 & 0.913 \\
Household size (number) & 11.18 & 9.393 & 10.86 & 9.625 \\
Farm size (hectare) & 0.950 & 0.985 & 1.009 & 0.928 \\
Access to credit (\%) & 0.171 & 0.060 & 0.138 & 0.088 \\
Extension access (\%) & 0.868 & 0.238 & 0.663 & 0.413 \\
Cattle ownership (\%) & 0.092 & 0.190 & 0.188 & 0.100 \\
Subsidy (\%) & 0.947 & 0.845 & 0.950 & 0.838 \\
Perceived cost of adoption (\%) & 0.881 & 0.845 & 0.800 & 0.925 \\
Farming experience (years) & 18.80 & 15.14 & 18.23 & 15.54 \\
\hline
\end{tabular}

Table 3 RBP model estimates of FBO membership and adoption of improved varieties

\begin{tabular}{|c|c|c|c|c|}
\hline \multirow[t]{2}{*}{ Variable } & \multicolumn{2}{|c|}{ FBO membership } & \multicolumn{2}{|c|}{ Adoption of IMVs } \\
\hline & Coefficient & Std. Dev. & Coefficient & Std. Dev. \\
\hline Sex & -0.179 & 0.639 & $-0.745^{* *}$ & 0.318 \\
\hline Age & 0.012 & 0.447 & -0.008 & 0.013 \\
\hline Educational status & 0.485 & 0.116 & $0.391 *$ & 0.237 \\
\hline Marital status & $1.486 * * *$ & 0.001 & 0.460 & 0.379 \\
\hline Farming experience & 0.007 & 0.702 & $0.025^{*}$ & 0.015 \\
\hline Farm size & $-0.607 *$ & 0.051 & -0.083 & 0.184 \\
\hline Household size & 0.017 & 0.526 & 0.028 & 0.022 \\
\hline Extension contact & $2.040 * * *$ & 0.000 & $1.365 * * *$ & 0.233 \\
\hline Cattle ownership & $-0.770 *$ & 0.053 & 0.017 & 0.288 \\
\hline Access to credit & & & 0.334 & 0.273 \\
\hline Subsidy & & & $0.711 * *$ & 0.354 \\
\hline Cost of adoption & & & $-0.648 * *$ & 0.277 \\
\hline Farmer group membership & & & $-1.514 * * *$ & 0.186 \\
\hline Constant & $-2.653 * * *$ & 0.000 & -0.311 & 0.673 \\
\hline
\end{tabular}

***, ** and * indicate statistical significance at 1, 5 and 10 percent levels, respectively. Likelihood-ratio test of rho $=0$ : $\operatorname{chi} 2(1)=5.3175$, Prob $>$ chi $2=0.021$.

\section{Determinants of farmer group membership}

For the FBO participation model, the results in Table 3 indicate that membership in FBOs is higher for married respondents, indicating that the choice to belong to a farmer group is influenced by the marital status of the respondent. However, Etwire et al. (2013) observed that marital status had no significant effect on farmers' decision to participate in agricultural projects in Ghana. Furthermore, farmers with smaller farms were more likely to participate in farmer groups compared to those with larger farms. Land-constrained farmers may be relatively poorer, which may influence their decision to join farmer groups as a result of the perceived benefits. The result is however at variance with the findings of a study on the determinants and impact of farmer collective action in Kenya by Fischer and Qaim (2012) which showed a higher probability of farmers with larger farms to join farmer groups compared to those with smaller farms. Asante et al. (2011) also reported a positive influence of farm size on farmer group membership in Ghana.

The result also indicate that extension contact increases the probability to participate in farmer-based organizations. The result is consistent with the extant literature and a priori expectation due to the increasing role of FBOs as conduits for extension delivery among poor people in developing countries. The result agrees with the findings of Tolno et al. (2015) in a study involving potato farmers in Guinea. Extension agents interact with farmers and share information on the benefits of joining farmer groups, thus influencing farmer's decision to participate in groups. Etwire et al. (2013) also observed that the likelihood of farmers to participate in agricultural projects increased with the number of extension contacts in a study involving farmers in Ghana.

In addition, the study revealed an inverse relation between cattle ownership and participation in farmerbased organizations. This implies that owners of cattle have a lower propensity to participate in farmer-based organizations. Cattle ownership was included as a proxy variable for wealth status of the respondent. Thus, participation in farmer groups was found to be lower for wealthier household heads in the study area.

\section{Determinants of improved variety adoption}

The estimates of the determinants of improved variety adoption are presented in the 4 th and 5 th columns of Table 3 . The results indicate that adoption of improved maize varieties is higher for female farmers. In other words, male 
farmers are more likely to cultivate traditional varieties. This result does not lend itself to easy interpretation. However, adoption of traditional varieties is a risk-averse behaviour of farmers, and therefore suggests that male farmers in the study area may be more risk-averse in their choice of crop varieties. The result agrees with Mwangi $\boldsymbol{e t}$ al. (2015) who found that men were less likely to adopt cover crops for weed management in Kenya. The result is however contrary to the findings of Kalinda et al. (2014) which showed that male farmers adopted improved technology more than female farmers.

The results also indicate that adoption of improved varieties increased with education of the respondent. Farmers with formal education are more likely to adopt improved varieties compared to those without formal education. This result is consistent with a priori expectation because education enhances the human capital and the ability of the farmer to make informed decisions based on available information. The result agrees with Teklewold et al. (2016) and Yimer et al., (2019) in their adoption studies involving farmers in Ethiopia.

Adoption of improved variety also increased with farming experience, which is consistent with the extant literature. Farming experience, like education and training, enhances the human capital and the ability to make informed decisions. Through learning over a long period of time and information sharing, farmers may gain knowledge of productivity-enhancing technologies which may enhance their willingness to adopt high-yielding crop varieties. However, a study by Ebojei et al. (2012) found no significant influence of farming experience on adoption.

Another important human capital variable which positively influenced farmers' decision to adopt improved maize varieties is access to agricultural extension services. The result is consistent with a priori expectation and corroborated by the extant literature. Farmers receive agricultural information from extension agents who link farmers to research centers. As a result, extension agents facilitate access to information and technology transfer to farmers and therefore play an important role in farmers' adoption decisions. The result agrees with Yimer $\boldsymbol{e t}$ al., (2019) in their study in Ethiopia. The result is also in consonance with Mignouna et al. (2011) in their study of maize technology adoption in Western Kenya and Akudugu et al. (2012) who studied technology adoption by farmers in Ghana.

The results of the study further indicate that access to fertilizer subsidy is positively related to adoption of improved maize varieties at 5\% significance level. This shows that the likelihood to adopt improved maize varieties increases with access to fertilizer subsidy. The government of Ghana introduced the Fertilizer Subsidy Program (FSP) in 2008 to increase cereal production in Ghana. Technically, all cereal farmers are entitled to a subsidy. However, as with many other government interventions in the agricultural sector, not every farmer is able to access the input subsidy due to several challenges (see Yawson et al., 2010). A subsidy reduces the cost of production and the risk of adopting improved crop varieties, thus enhancing the likelihood of adoption. Similarly, Bezu et al. (2013) found a significant positive correlation between subsidy accessibility and adoption of improved maize varieties in Malawi.

Farmers' perception of the cost of adoption had a significant relationship with the decision to adopt improved maize varieties at 5\% level. The result indicates that adoption decreased with an increase in the perceived cost of adoption. The result is consistent with a priori expectation. As cost of adoption increases, many farmers are likely to choose varieties that are less costly to adopt. In a situation where the farmer faces liquidity constraints, it is unlikely that he or she will adopt a technology which is costly. However, with credit provision and adequate information on the yield potential of new varieties, farmers may be persuaded to adopt technologies which they perceive to be costlier. The result is in agreement with the findings of Lyimo et al. (2014) which stated that high cost of improved seeds hindered its adoption in Tanzania.

Finally, the variable of interest, farmer group membership portrayed a negative and significant relationship with adoption at $1 \%$ level. The result indicates that farmer group membership significantly decreases adoption of improved varieties. The result is contrary to a priori expectation because farmer groups are expected be serve as channels for extension delivery to farmers. Farmer groups also help members to acquire production inputs and credit for their members. The result however suggests that farmer groups in the study area are not effective in influencing technology adoption decisions of members. All though the result is hard to explain, Mwangi and Kariuki (2015) observed that social groups may have a negative impact on technology adoption in the event of free-riding behaviour by members.

\section{CONCLUSION AND RECOMMENDATIONS}

The study examined the effect of farmer group membership on improved variety adoption by maize farmers in Tolon District of northern Ghana. The study relied on cross-sectional data from 160 maize farmers and used a recursive bivariate probit model to estimate the influence of group membership on adoption. The study indicated a negative association between farmer group membership and adoption of improved maize varieties. This implies that farmer groups in the study area are not making a positive impact on their members in terms of decision to adopt improved seeds. Farmer groups in the country face challenges including politization of the groups, and lack of adequate support from both public and private institutions, which are likely to reduce their effectiveness. There is therefore the need to incentivize these groups, including the apex body responsible for their supervision so as to enhance the effectiveness of farmerbased organizations in the study area.

The results of the study also highlight the important role of agricultural extension, which is positively related to adoption decision and farmer group membership. Hence, efforts to enhance adoption of improved maize varieties and FBO membership must seek to address the specific factors influencing farmers' participation and adoption decisions, while paying particular attention to ways to enhance farmers' access to agricultural extension. 
Acknowledgments: The authors are grateful to the extension staff of the Ministry of Food and Agriculture at the Tolon District office for their assistance is the selection of communities for the data collection.

\section{REFERENCES}

AKUDUGU, M., GUO, E., and DADZIE, S. (2012). Adoption of Modern Agricultural Production Technologies by Farm Households in Ghana: What Factors Influence their Decisions? Journal of Biology, Agriculture and Healthcare, 2(3):1-13.

ASANTE, B. O., AFARINDASH, V. and SARPONG, D. B. (2011). Determinants of small-scale farmers decision to join farmer-based organizations in Ghana. African Journal of Agricultural Research, 6(10), 2273-2279.

BARHAM, J., and CHITEMI, C. (2009). Collective action initiatives to improve marketing performance: Lessons from farmer groups in Tanzania. Food policy, 34(1), 5359. DOI: https://doi.org/10.1016/j.foodpol.2008.10.002. BENIN, S., NKONYA, E., OKECHO, G., RANDRIAMAMONJY, J., KATO, E., LUBADDE, G., KYOTALIMYE, M. and BYEKWASO, F. (2011). Impact of Uganda's National Agricultural Advisory Services Program (Vol. 175). International Food Policy Research Institute (IFPRI).

BERNARD, T., and SPIELMAN, D. J. (2009). Reaching the rural poor through rural producer organizations? A study of agricultural marketing cooperatives in Ethiopia. Food policy, 34(1), 60-69. DOI: https://doi.org/10.1016/j.foodpol.2008.08.001.

BERNARD, T., COLLION, M.-H., DE JANVRY, A. and RONDOT, P. (2008). Do village organizations make a difference in African rural development? A study for Senegal and Burkina Faso. World Development, 36 (11): 21882204.

DOI: https://doi.org/10.1016/j.worlddev.2007.10.010. BEZU, S., KASSIE, G. T., SHIFERAW, B., and RICKER-GILBERT, J. (2014). Impact of improved maize adoption on welfare of farm households in Malawi: a panel data analysis. World Development, 59, 120-131. https://mpra.ub.uni-

muenchen.de/48763/1/MPRA paper_48763.pdf.

CHIBWANA, C., FISHER, M., JUMBE, C., MASTERS, W. A., and SHIVELY, G. (2010). Measuring the Impacts of Malawi's farm input subsidy program. African Journal of Agriculture and Resource Economics, 9(2), 132-147. https://ageconsearch.umn.edu/record/176511/files/5.\%20 Chibwana\%20et\%20al.pdf.

DAVIS, K., NKONYA, E., KATO, E., MEKONNEN, D. A., ODENDO, M., MIIRO, R., and NKUBA, J. (2012). Impact of farmer field schools on agricultural productivity and poverty in East Africa. World Development, 40(2), 402-413.

DOI:

https://doi.org/10.1016/j.worlddev.2011.05.019.

DEBELA, M., DIRIBA, S., and BEKELE, H. (2018). Impact of cooperatives membership on economy in Eastern Oromia: the case of Haramaya Agricultural Farmers' Cooperative Union (HAFCU). Annals of Public and Cooperative Economics, 89(2), 361-376. DOI: https://onlinelibrary.wiley.com/doi/abs/10.1111/apce.121 $\underline{75}$.
DEVELOPMENT NETWORK OF INDIGENOUS VOLUNTARY ASSOCIATIONS (DENIVA) (2005). Effectiveness of Farmer-groups as Viable Institutions for Farmer Empowerment and Poverty Reduction in the Implementation of the Plan for the Modernization of Agriculture

http://www.deniva.or.ug/files/programmeagriculturetrade research farmergroups.pdf.

EBOJEI, C. O., AYINDE, T. B., and AKOGWU, G. O. (2012). Socio-economic factors influencing the adoption of hybrid maize in Giwa Local Government Area of Kaduna State, Nigeria. Journal of Agricultural Sciences, 7(1), 23-32. DOI: http://dx.doi.org/10.4038/jas.v7i1.4064 ETWIRE, P.M., DOGBE, W., WIREDU, A.N, MARTEY, E., ETWIRE, E., OWUSU, R.K, and WAHAGA, E. (2013). Factors Influencing Farmer's Participation in Agricultural Projects: The case of the Agricultural Value Chain Mentorship Project in the Northern Region of Ghana. Journal of Economics and Sustainable Development, 4(10), 36-43.

FEDER, G., JUST, R. E., and ZILBERMAN, D. (1985). Adoption of agricultural innovations in developing countries: A survey. Economic development and cultural change, 33(2), 255-298. DOI: https://doi.org/10.1086/451461

FISCHER, E. and QAIM, M. (2012). Linking smallholders to markets: determinants and impacts of farmer collective action in Kenya. World Development, 40(6), 1255-1268. DOI: https://doi.org/10.1016/j.worlddev.2011.11.018

GATZWEILER, F.W. and VON BRAUN J. (eds.) (2016). Technological and Institutional Innovations for Marginalized Smallholders in Agricultural Development, Springer International Publishing. DOI: 10.1007/978-3319-25718-1

GOVERNMENT OF GHANA (2017). The Budget Statement and Economic Policy of the Government of Ghana for the 2017 Financial Year (1st ed.). Accra: Ministry of Finance. http://www.mofep.gov.gh/

HAZELL, P., C. POULTON, S. WIGGINS, and A. DORWARD (2010). The future of small farms: trajectories and policy priorities. World Development, 38(10): 1349-1361. DOI: https://doi:10.1016/j.worlddev.2009.06.012.

ISSER (INSTITUTE OF STATISTICAL, SOCIAL AND ECONOMIC RESEARCH) (2016). The state of the Ghanaian economy. Legon, Accra: University of Ghana.

KALINDA, T., TEMBO, G., KUNTASHULA, E., and LUSAKA, Z. (2014). Adoption of improved maize seed varieties in Southern Zambia. Asian Journal of Agricultural Sciences, 6(1), 33-39.

LYIMO, S., MDURUM, Z. and DE GROOTE, H. (2014). The use of improved maize varieties in Tanzania. African Journal of Agricultural Research, 9(7), 643-657. http://www.academicjournals.org/AJAR.

MAAIF (2010). Ministry of Agriculture, Animal Industry and Fisheries. Agriculture for food and income security: Agriculture Sector Development Strategy and Investment Plan: 2010/11-2014/15. MAAIF, Kampala, Uganda.

MIGNOUNA, B., MANYONG, M., RUSIKE, J., MUTABAZI, S. and SENKONDO, M. (2011). Determinants of Adopting Imazapyr-Resistant Maize 
Technology and its Impact on Household Income in Western Kenya: AgBioforum, 14(3), 158-163.

MWANGI, H. W., KIHURANI, A. W., WESONGA, J. M., ARIGA, E. S. and KANAMPIU, F. (2015). Factors influencing adoption of cover crops for weed management in Machakos and Makueni counties of Kenya. European Journal of Agronomy, 69, 1-9. DOI: https://doi.org/10.1016/j.eja.2015.05.001.

MWANGI, M. and KARIUKI, S. (2015). Factors determining adoption of new agricultural technology by smallholder farmers in developing countries. Journal of Economics and sustainable development, 6(5): 208-216. https://pdfs.semanticscholar.org/8e9b/28e14286f65a9168 738a97c74a256bc8e4c3.pdf.

MWAURA, F. (2014). Effect of farmer group membership on agricultural technology adoption and crop productivity in Uganda. African Crop Science Journal, 22, 917-927.

https://www.ajol.info/index.php/acsj/article/viewFile/108 510/98319.

TEKLEWOLD, H., MEKONNEN, A., KOHLIN, G. and DI FALCO, S. (2017). Does adoption of multiple climatesmart practices improve farmers' climate resilience? Empirical evidence from the Nile Basin of Ethiopia. Climate Change Economics, 8(01), 1750001. DOI: https://doi.org/10.1142/S2010007817500014.
TOLNO, E., KOBAYASHI, H., ICHIZEN, M., ESHAM, M. and BALDE, B. S. (2015). Economic analysis of the role of farmer organizations in enhancing smallholder potato farmers' income in middle Guinea. Journal of Agricultural Science, 7(3), 123. DOI: http://dx.doi.org/10.5539/jas.v7n3p123.

ULIWA, P. and FISHER, D. (2004): Assessment of Tanzania's producer Organizations. Experience and Environment. USAID Economic growth office.

YAWSON, D. O., ARMAH, F. A., AFRIFA, E. K. A. and DADZIE S. K. N. (2010). Ghana's Fertiliser Subsidy Policy: Early field lessons from farmers in the Central Region. Journal of Sustainable Development in Africa, 12(3): 191-203.

YIMER, F., ABAY, K. and DEGU, T. (2019). Evaluation of Modern Agricultural Technologies Adoption and Impact of Adoption on Productivity. FARA Research Report Vol 4(3): 26. 